\title{
Development of the Concept of Agroecology in Europe: A Review
}

\author{
Felipe Gallardo-López ${ }^{1, *(D)}$, Mario Alejandro Hernández-Chontal ${ }^{1}$ (D), \\ Pedro Cisneros-Saguilán ${ }^{2}$ (D) and Ariadna Linares-Gabriel ${ }^{1}$ (D) \\ 1 Postgrado en Agroecosistemas Tropicales, Colegio de Postgraduados, Campus Veracruz, \\ Veracruz 91700, Mexico; hernandez.mario@colpos.mx (M.A.H.-C.); linares.ariadna@colpos.mx (A.L.-G.) \\ 2 Departamento de Ciencias Agropecuarias, Instituto Tecnológico de Pinotepa, \\ Tecnologico Nacional de México, Oaxaca 71600, Mexico; pedro_cs@itp.edu.mx \\ * Correspondence: felipegl@colpos.mx; Tel.: +52-285-100-2143
}

Received: 27 February 2018; Accepted: 3 April 2018; Published: 17 April 2018

\begin{abstract}
The concept of Agroecology is still not widely discussed in European countries. Therefore, the aim of this review is to present a qualitative and quantitative mixed analysis of this conceptualization based on research papers to provide initial answers to the following questions: How has the agroecology been used in terms of social movement, science and agricultural practice in the European countries? At which scales has it been applied? Which factors have influenced its application? Speech analysis and multivariable techniques are applied to systematized information. According to found results, the concept of agroecology is mainly conceived as science, then as practice and to a lesser degree as a social movement. There is a predominance of studies at plot level, with a tendency to include physical-biological factors; and at agroecosystem, regional and agri-food system levels, including designers, landscapes and consumers. There is a conceptual evolution in extensive quantitative and intensive qualitative standings when the agroecology incorporates more factors, such as economic, social, and, to a lesser extent, cultural and political, and becomes more transdisciplinary as a response to more complex phenomena that support the genesis and development of this concept. In this regard, a greater balance between its conceptions (science, practice and social movement) is recommended to achieve a better dialogue between abstract and empirical levels.
\end{abstract}

Keywords: transdiscipline; sustainability; agroecosystems; agri-food systems

\section{Introduction}

Agroecology emerged as an approach to understand the ecological principles of traditional agricultural systems, and as a discipline that defines, classifies and studies agricultural systems from an ecological and socioeconomic perspective, fostering, through their methods and principles, the sustainable development of agroecosystems [1,2]. Its history begins in 1928, when the concept of agroecology was first used to describe the use of ecological methods in the research of commercial plants; later, between the 1930s and the 1960s, several authors wrote their results of research in this area, but without using the term explicitly [3]. Nevertheless, the field of this discipline has gained considerable recognition in recent decades, evolving from the application of agroecological concepts and principles until the adoption of a diversity of perspectives, which vary according to academic content, research methods and practical applications and policies [3-5].

Although agroecology has existed for several decades, different concepts and interpretations have emerged and been discussed in recent years, some of them interpret agroecology as a science, as a social movement or as an agricultural practice [6]; others consider agroecology as a transdisciplinary, 
participatory and action-oriented approach [2]; and some even suggest to adopt it as a political action [7]. According to Toledo [8], the triple dimension of agroecology makes it not only an innovative and critical epistemology, strongly linked to other "hybrid disciplines", such as political ecology, ecological economics, environmental history and ethnoecology, but it also turns agroecology into a productive practice in open opposition to the task of conventional agronomy, which is generally at the service of large landowners and corporations as well as into a social movement linked to the demands of small producers, peasants and indigenous peoples.

During the evolution of the application of the concept, agroecology has also changed in scale, going from a plot or field (from 1930s to 1960s) to an agroecosystem level (1970s to 2000), and finally a food system scale [3,6]. Recently, Wezel et al. [9] proposed a regional scale or "agroecological territories" to characterize certain defined areas in transition towards sustainable agriculture based on agroecological practices. This evolution has led to the generation and accumulation of knowledge with an integrating approach that demonstrates its contribution to the productivity of agricultural systems from their different perspectives and in their different scales of study (at plot, agroecosystem, regional and food system level).

The contribution of agroecology as a scientific discipline has traveled from the agroecosystems approach, where components and functions of natural ecosystems, including local knowledge and production strategies based on ecological principles (ecological pest management, association of crops and agroforestry systems) are suggested [10-12]; up to the feasibility of complementing the approach of climate-smart agriculture to contribute to the mitigation and adaptation to climate change, food security and the organizational strengthening of producers $[4,10,13]$.

Although it is recognized that the term agroecology was used for the first time in the 1920s and 1930s (1928 and 1930) by authors from Russia and the European Union (France, Germany and Italy) $[6,10,14]$, little has been systematized and mapped for the use of the concept in Europe, as it has been in other territorial contexts, such as the case of Latin America [14], and especially Mexico, where the agroecological benefits of many traditional practices have been systematized and documented, as well as various research approaches in this area [14-16].

Given this background, it is necessary to document the concept of agroecology in the context of European countries and regions: How has it been used in terms of social movement, science and practice? What are the scales of its application? Which factors have been included in its application? Since there is no substantial document that identifies the use and evolution of the concept of agroecology in different European countries, causing confusion among scientists, the public in general, and therefore in the design and implementation of policies, this document presents a systematization and analysis of scientific documents with the purpose of giving initial answers to these questions.

\section{Materials and Methods}

To find the concept, a query was made to the Scopus database on 13 December 2017, using the word "agroecology". The search was limited to scientific research published by European countries. The Scopus database had a list of 574 documents (mainly articles, reviews, scientific notes, books and book chapters) written in English, French, German, Hungarian, Polish, Slovak and Spanish. The collected information, containing the name of the authors, title, year of publication, volume, number, pages, affiliations of the authors, type of document, summary, link and digital object identifier (DOI) was stored in an Excel spreadsheet. Link and DOI were used to download the complete documents in PDF format.

The documents were reviewed, excluding papers with references to research carried out outside the European countries, resulting in 424 documents from the period 1989-2018. For each document, a record was created with the title, author(s), abstract, keywords and conclusions, and it was stored in a Word file. The examination of information was conducted through a text analysis, according to the 
categories described in Table 1, and using NVivo 11 Pro for Windows software, applying the content analysis technique [17] to textual quotations in their original language.

The categories of analysis were established a priori as science, social movement (movement) and agricultural practice (practice), considering the concepts described by Wezel, Bellon, Doré, Francis, Vallod and David [6].

To map the spatial distribution of the documents, the country where the research was carried out and their main objective were identified and classified, resulting in 201 documents, out of 424 (Figure 1). The 223 documents that were excluded did not mention the place of research or they were review papers.

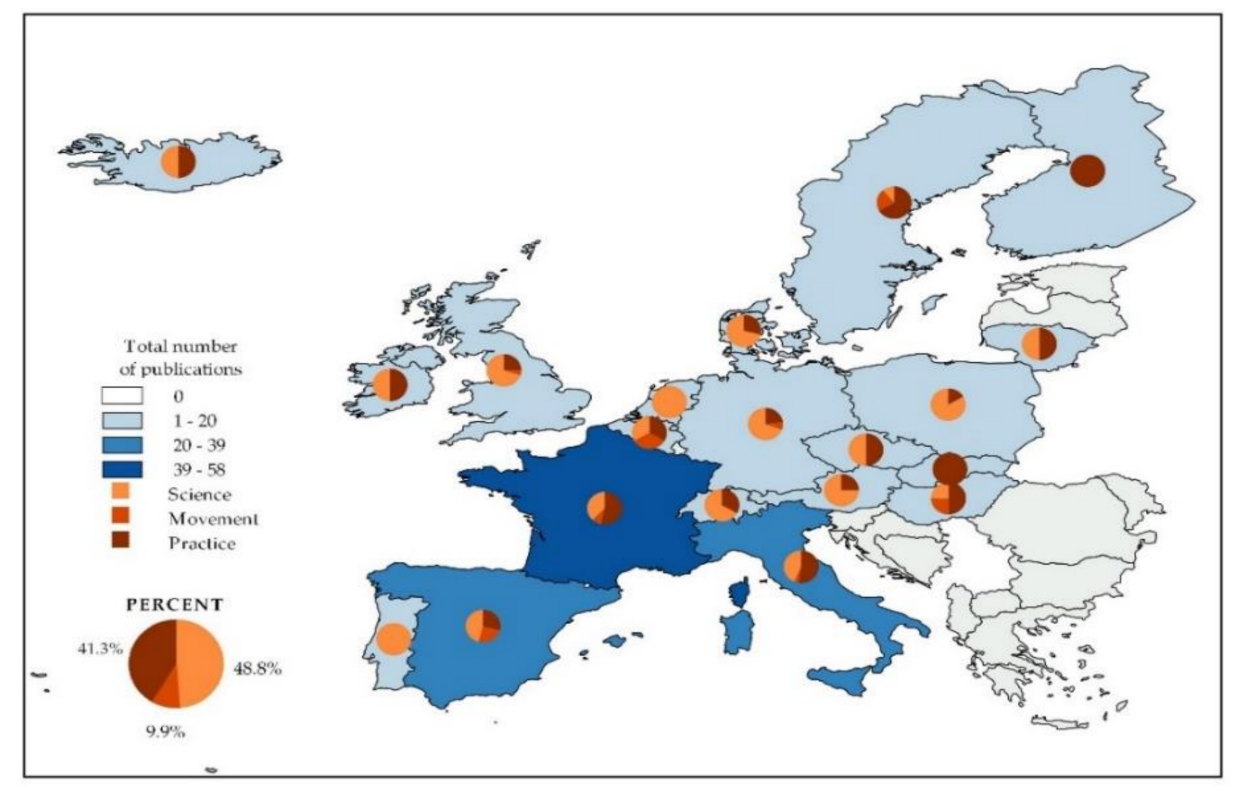

Figure 1. Spatial distribution of documents according to the use of the concept of agroecology in Europe.

The number of cited documents and the quantity of textual quotes was determined by the categories of analysis (science, practice and movement). In this regard, the documents could contain textual quotations from one, multiple and/or null category of analysis. Results and discussion were obtained from relevant textual quotes, as basis to answer the questions projected in this research.

With this information, an Excel database was generated, and exported to the statistical program Statistica ${ }^{\circledR}$ version 7 [18] to perform an exploratory data analysis [19] over the concept of agroecology as science, practice and social movement in percentage, and the total number of documents containing these terms by country. Subsequently, two multivariate techniques were applied to identify groups of countries according to the use of the concept. The first was a dendrogram using the Euclidean distances and the complex linkage algorithm [20]. Since this technique showed the conformation of three groups, the second technique, the k-means, was applied to identify these three groups, their descriptive statistics and their members.

We contemplate that, since the analyzed information was obtained from a scientific database, our results may show a bias towards the category of "science". Therefore, these findings must be analyzed only as initial elements contributing to a general conceptualization mapping of agroecology in Europe. 
Table 1. Description of the categories and elements for the analysis of the discourse over the concept of agroecology in European countries.

\begin{tabular}{|c|c|c|}
\hline Element & Category & Description \\
\hline \multirow{3}{*}{ Conceptualization } & Science & $\begin{array}{l}\text { Agroecology is a scientific discipline. New and broader definitions } \\
\text { of agroecology [5]. }\end{array}$ \\
\hline & Social movement & $\begin{array}{l}\text { It expresses a new way of considering agriculture and its } \\
\text { relationships with society. It emerges as an environmental } \\
\text { movement against industrial agriculture [5]. }\end{array}$ \\
\hline & $\begin{array}{l}\text { Agricultural } \\
\text { practice }\end{array}$ & $\begin{array}{l}\text { Agroecology is seen as the basis of an agricultural development } \\
\text { framework, in the sense of helping local farmers to improve their } \\
\text { agricultural practices as an alternative to intensive agriculture [5]. }\end{array}$ \\
\hline \multirow{4}{*}{ Scale } & Cultivation system & $\begin{array}{l}\text { Communities formed by a complex interaction of crop populations: } \\
\text { weeds, insects and microorganisms [21]. They integrate the } \\
\text { interaction of three basic components: biotic, abiotic and technology } \\
\text { [22]. }\end{array}$ \\
\hline & Agroecosystem & $\begin{array}{l}\text { The agroecosystem is considered a conceptual model to study the } \\
\text { complexity of agriculture, which considers within its structure the } \\
\text { socioeconomic (the producer and his family) and the productive } \\
\text { components (the farm, production unit, and production system) } \\
\text { [23]. }\end{array}$ \\
\hline & Regional scale & $\begin{array}{l}\text { Agroecological territory where: (a) there is a transition to } \\
\text { sustainable agriculture based on agroecological practices; (b) } \\
\text { conservation of biodiversity and resources is considered; (c) food } \\
\text { systems are embedded in the space; and (d) stakeholders support } \\
\text { the transition towards sustainable agricultural and food systems [9]. }\end{array}$ \\
\hline & Agri-food system & $\begin{array}{l}\text { Activities that contribute to the formation and distribution of food } \\
\text { products and, consequently, to the fulfillment of the function of } \\
\text { human nutrition in a given society and in a well-defined space and } \\
\text { time [24]. }\end{array}$ \\
\hline \multirow{3}{*}{ Factors } & Physical-biological & $\begin{array}{l}\text { It is related to flora, macrofauna, mesofauna, microfauna and } \\
\text { microbiota intervention in the mobility of the biogeochemical cycles } \\
\text { of the elements and the mechanical effects of animals and plants } \\
\text { [25]. }\end{array}$ \\
\hline & $\begin{array}{l}\text { Social, cultural and } \\
\text { economics }\end{array}$ & $\begin{array}{l}\text { It is related to improving the rural standard of living through food } \\
\text { self-sufficiency, satisfaction of local needs, independence and } \\
\text { autonomy, endogenous development and small units, participation } \\
\text { and decision making, with the efficient use of goods, services } \\
\text { (production) and equitable distribution, without damaging the } \\
\text { renewal, reproduction and distribution of the agroecosystem [26]. }\end{array}$ \\
\hline & Political & $\begin{array}{l}\text { It refers to the set of stable power relationships (regulations and } \\
\text { legal norms) or decisions over the relationships between natural } \\
\text { and social processes [27]. }\end{array}$ \\
\hline
\end{tabular}

\section{Results and Discussion}

\subsection{Spatial Distribution of the Conceptualization of Agroecology in Europe}

According to the general analysis, in Europe, agroecology is mainly conceived as a science, followed by as a practice and to a lesser degree as a social movement (Figure 1). In this regard, the multivariate techniques identified three groups of countries (Table 2). In the first one, there are initial contributions, and agroecology is considered as a science (Romania, Portugal and Netherlands); in the second, it is conceived mainly as a science, followed by practice and with marginal conception as a movement (Switzerland, Poland, Denmark, Germany, United Kingdom, Austria and Spain); and, in the third and more prolific group, agroecology, considered as a practice, predominates, followed by science and to a lesser degree as a movement (Finland, Slovakia, Iceland, Ireland, Lithuania, Belgium, Czech Republic, Norway, Hungary, Sweden, Italy and France). Similar results were reported by Wezel et 
al. [6], for the case of Germany and France. The distribution obtained by these authors and the results of this study differ, possibly due to the expansion of the concept and the time elapsed since they performed their studies.

The relevance of agroecology in the countries with the largest number of scientific documents, as observed in the spatial distribution, could be influenced by the origins of agroecology in Europe, which began in Andalusia, Spain, where agroecological thinking has become a pillar of its own definition as scientific thought [28]. Besides, these results show an expansion (with science-practice and practice-science tendencies in countries from Clusters 2 and 3, Table 2) of the diversification of the concept, with a considerable multiplication. According to Toledo [8], this multi-dimensional character of agroecology manages to respond 10 social and ecological demands to overcome a similar number of problems caused by the crisis of modernity: (1) maintenance of biodiversity; (2) conservation of forest cover; (3) conservation of soil and water; (4) capture of carbon; (5) suppression of agro-toxic and transgenic organisms; (6) agricultural equity; (7) food sovereignty; (8) self-management and local self-sufficiency; (9) fair and organic markets; and (10) knowledge dialogues and participatory research.

Table 2. Quantity and grouping of European countries according to the conceptualization of agroecology (science, social movement or practice).

\begin{tabular}{|c|c|c|c|c|c|c|c|c|c|}
\hline \multirow[t]{2}{*}{ Cluster } & \multirow[t]{2}{*}{ Countries } & \multicolumn{2}{|c|}{ Science $(\%)$} & \multicolumn{2}{|c|}{ Movement (\%) } & \multicolumn{2}{|c|}{ Practice (\%) } & \multicolumn{2}{|c|}{$\begin{array}{c}\text { Total Number of } \\
\text { Documents }\end{array}$} \\
\hline & & Mean & $\mathrm{SD}^{1}$ & Mean & SD & Mean & SD & Mean & SD \\
\hline 1 & $\begin{array}{l}\text { Romania, Portugal and } \\
\text { Netherlands }\end{array}$ & 100 & 0 & 0 & 0 & 0 & 0 & 2.3 & 1.5 \\
\hline 2 & $\begin{array}{l}\text { Switzerland, Poland, } \\
\text { Denmark, Germany, } \\
\text { United Kingdom, Austria } \\
\text { and Spain }\end{array}$ & 68.7 & 11.4 & 5.3 & 9.1 & 25.8 & 5.2 & 11 & 8.2 \\
\hline 3 & $\begin{array}{l}\text { Finland, Slovakia, Iceland, } \\
\text { Ireland, Lithuania, } \\
\text { Belgium, Czech Republic, } \\
\text { Norway, Hungary, } \\
\text { Sweden, Italy and France }\end{array}$ & 31.3 & 19.1 & 9.8 & 12.7 & 58.8 & 20.5 & 9.7 & 16.3 \\
\hline
\end{tabular}

\subsection{The Concept of Agroecology as Science}

The textual analysis and the quantity of textual quotes linked to the a-priori categories obtained from the documents identified three axes of analysis for the concept of agroecology as science: (1) the legal perspective; (2) the evolution of the concept of agroecology; and (3) the role of agroecology to solve empirical problems. These axes are described below.

\subsubsection{The Legal Perspective}

This analytical axis is mainly oriented towards the search for an agroecological regulation, in addition to the fact that agroecology has been integrated by multiple disciplines in which agronomy, ecology, sociology, economics and philosophy stand out, to conform its transdisciplinary nature [29]. In this regard, some considerations from Monteduro et al. [30] are cited, emphasizing that "There is a need to adopt a transdisciplinary approach to multifunctional agriculture in order to integrate the agroecological paradigm in legal regulation", while Hospes [31] suggested that "Agroecology as a transdisciplinary field of studies of agroecosystems can benefit enormously from the use of a legal pluralistic perspective on law, social fields, and sovereignty in four different ways: by exploring the interconnectedness of different legal systems and normative orders with agroecosystems, by studying how agroecosystems are linked to one or more semiautonomous social fields". 
In this analytical axis, agroecology has not yet developed instruments and approaches to elaborate state and regional strategies where the political and institutional aspects could play a key role within the transdisciplinarity [7]; therefore, the legal aspects are outside the research lines of agroecology, a missing linkage that must be included, as Monteduro suggested [32]. In this sense, this research was able to identify its pertinence in the context of agriculture and the relationships between law and agroecology as disciplines, which allowed adopting a transdisciplinary approach to integrate the agroecological paradigm into legal regulations [29] and contribute with the models of the old law system (specially the Roman law) to the agroecological research [33]. This way, the agroecological importance of an administrative programming and planning instrument is represented by Rural Development Programs, although little has been investigated by legal doctrines [34]. In regard to this situation, Monteduro [32] suggested that a law of sustainable agricultural ecosystems should be developed in which the entire field of environmental law should be reconsidered and reconstructed as a general and special law where ecosystems are considered as providers of diversified public services.

\subsubsection{Evolution of the Concept of Agroecology}

In this analytical axis, it was found that agroecology, in its attempt to achieve food security and sovereignty, has proposed the convergence of different disciplines, becoming a transdisciplinary field. In this context, agroecology has gone from dealing only with the ecological aspects and the farming system, to the point where political and social aspects are involved in the foreground. In this regard, we take the opinion of Sanderson Bellamy and Ioris [35], who mentioned that "Agroecology has been conceptualized as a farmer-led countermovement against the modern agri-food system based on the holistic practices of agroecological food production (local, participatory and action-orientated) alongside the principles of sustainability and autonomy in food production".

Both the transdisciplinary nature and its three-dimensional approach (science, practice and movement) have transform agroecology into a way of collective actions against the dominant agri-food regime, creating alternatives towards food sovereignty [36]. This has led to rethink the scope of agroecology and therefore, to evolve the scientific thinking of the concept. In this way, the new approaches to production, grouped under the term "agroecology", are not only based on the modern advances of agricultural sciences, but also on the traditional knowledge of rural populations [37]. In this respect, Meynard [38] manifested that "Agroecology has become an innovative project, positioning itsetf in the action, and in the fields of natural, economic and political sciences. Agroecology lead us to explore new fields of knowledge at the interfaces between disciplines, the agronomic impacts of biological regulations or the socioecolgical systems".

With the above mentioned, it is identified that agroecology is a young field of environmental, social and political-economic activity, with debates and definitions that are evolving. Although the agricultural science predominated in its origin, it has become a transdisciplinary field in which political and social issues are now becoming more important [35]. In this sense, agroecology focused initially on crop systems, then on agroecosystems and finally on the broader agri-food systems, in response to the problems derived from an increasingly globalized and industrialized agro-food system [28].

\subsubsection{The Function of Agroecology to Solve Empirical Problems}

In this analytical axis, it can be seen that the evolution of the concept of agroecology and agroecological thinking has transformed the dimensions of agriculture, beginning from its ecological and environmental aspects until the need to address agricultural and rural development processes to reach sustainability; therefore, agroecosystems need high quality production to face the current context of agriculture. For these reasons, Bergez et al. [39] suggested that "Due to significant changes in agro-ecological contexts, farmers need new solutions to produce goods". Struik and Kuyper [40] mentioned that "We argue that sustainable intensification should be considered as a process of enquiry and analysis for navigating and sorting out the issues and concerns in agronomy". 
Given that agriculture currently faces major challenges, there is a need to guarantee various ecosystem services in addition to food production. In this regard, ecological intensification contributes to the use of biological regulations in order to properly manage agroecosystems at their various scales [41,42]. An approach to identify and design land systems oriented to the future is also indispensable, where options for strategic decision making regarding land use policies should be under consideration [43]. Therefore, it is essential to develop future strategies compatible with the environment for the use of land, and achieve agricultural productivity and sustainability by improving information over agroecosystems [44]. The need to address development processes towards sustainability requires innovative farming systems that lead to high quality production and limit the use of chemical products to meet the challenges of agriculture [45]. Accordingly, the sustainability of the farm can only be achieved through adaptability and change, considering resilience thinking with its focus on the interdependence of social and ecological systems [46], which guarantees the maintenance of sufficient and nutritious food production against chronic and acute environmental disturbances [47].

\subsection{The Concept of Agroecology as Agricultural Practice}

The ultimate goal of agroecology is to contribute to sustainable agricultural and rural development; thus, an intermediate goal as a practice is to contribute to improve agricultural practices as alternatives for conventional agriculture. In this sense, during the analysis of agroecology as a practice, three important elements were found: (1) crop production; (2) animal production; and (3) landscape diversity.

\subsubsection{Agroecology as Agricultural Practice in Crop Production}

Some authors mention that agriculture in Europe has gone from conventional agricultural systems that depended on high inputs of toxic fertilizers and pesticides (which are a threat to human health and the environment), to sustainable production systems that are currently being developed as more secure alternatives. For example, organic and low input systems, which use mechanical and biological methods, instead of toxic substances to control plagues [48]. This is similar to the case of Spain with the Integrate Pest Management (IPM), or the case of France that has tried to adopt agroecological innovations aimed at reducing the use of pesticides for banana production in the French Antilles [49]. In this regard, Rusch et al. [50] reported the positive and practical effects of the ecological intensification through the heterogeneity of the landscape in the biological control of vineyard pests, maintaining that the monitoring of these practices by farmers is an original approach that seeks to identify and analyze alternative systems and supports the development of these techniques. According to Phocas et al. [51], agroecology uses ecological processes and local resources instead of chemical inputs to develop productive and resilient systems.

\subsubsection{Agroecology as Agricultural Practice in Animal Production}

This research found that agroecological practices focused on livestock production are mainly for the management of sheep, cattle and swine. For example, in the case of the mountainous areas of the French Mediterranean, farmers depend on various resources to feed their animals and the way in which they combine these resources plays an important role from an agroecological perspective [52]. It is documented that in the French mountainous areas there are internal and contextual factors that influence the restructuring of dairy production. Among these factors are the size of the farm, the corporate legal status and the level of specialization, which are positively associated with farm growth rate, also highlighting viable diversification strategies through agricultural processing or the contracting of agro-environmental schemes [53]. Another aspect referring to agroecological practices was analyzed at a mountainous site in France, finding a potential contribution of livestock farms in the management of the invasion of shrubs, by implementing a variety of appropriate management and feeding practices of livestock and soil conservation [54]. 
In the case of cattle farming, and in response to the fact that this activity has been judged as one of the main contributors to environmental deterioration due to the use of unsustainable technologies and the emission of greenhouse gases into the atmosphere [55,56], some research was found to revert this problem. One study conducted in Sweden, Denmark, France and Italy revealed that changes in manure management (separation and incineration of the solid fraction) could induce significant changes in $\mathrm{CH}_{4}$ and $\mathrm{N}_{2} \mathrm{O}$ emissions, as well as carbon sequestration [57]. Other investigation over the systems of organic cattle farms in the northwest of Europe demonstrated how the special organic conceptions of animal welfare, related to the general principles of organic agriculture, can contribute to cattle producers understanding the behavior and natural needs of animals in the context of agricultural systems; for example, feeding ruminants as ruminants and not as monogastric organisms [58].

\subsubsection{Agroecology as Agricultural Practice in Biodiversity and Landscape}

Another important objective of agroecology is to promote diverse biological communities considering the important role of soil biodiversity for their operation [59]. In this sense, it is proposed that the integrated or agroecological agricultural systems should be based as much as possible on the services provided by the agroecosystems according to their principles and characteristics; for example, a condition that can reinforce ecosystem services is to recapitalize ecosystems by investing in soil organic matter (humus) and ecological infrastructure [60]. In the case of Spain, the use of a support system for land evaluation decisions was reported. This system considers the multifunctional evaluation of soil quality using data collected from surveys over land use, and based on them, it designs the most sustainable land use and management practices for Mediterranean referenced sites located in the province of Seville [61]. The author of this document concludes: "This agro-ecological approach can be especially useful when formulating soil-specific agricultural practices to reverse environmental degradation, based on the spatial variability of soils and related resources".

Another relevant aspect was discussed by Salliou and Barnaurd (2017) over the case of an apple production area in the Southwest of France. It was found that, in most natural resource management situations, potential agroecological means considering the importance of the complexity of landscape and the natural enemies to control plagues and reduce the use of pesticides, are not necessarily considered as resources for their potential users (agricultural producers), since in some cases they were perceived more as a source of pests [62]. In this sense, for the European context, it has been recommended to implement agroforestry strategies as key elements for agriculture and food security to optimize sustainable intensification and balance the competitive demands over land for the production of food and energy. At the same time, the provision of ecosystem services is guaranteed and yields are maintained or increased [63]. The approach of agroecology to positively impact biodiversity and the agricultural landscape is a fundamental characteristic of agroecology that has allowed it to be considered as one of the epistemological currents of sustainability, with a greater contribution to the design, management and evaluation of the agroecosystems [55].

\subsection{Agroecology as Social Movement}

The use of the concept of agroecology as a social movement has been strongly influenced by environmental movements against agricultural industry [5], and, in the case of Europe, research documents mainly address two aspects: (1) transgenic and environmental problems; and (2) food security and sovereignty.

\subsubsection{Transgenic and Environmental Problems}

Coexistence measures between genetically modified and non-genetically modified crops at farm level are considered an essential part of European policies to guarantee the freedom of choice of farmers and consumers. Suitable coexistence measures should not tip the balance against GM crops or distort farmers' decisions to grow them or not [64]. In this sense, advocates of biotechnology have begun to call environmental movements to abandon their campaigns against genetically modified organisms and, 
in the case of organic agriculture, to reconsider their exclusion from genetic modification [65]. On the other side, agricultural law and environmental law are two different legal branches, with common points between the two (agricultural law regulates environmental protection and environmental law regulates agricultural pollution) [66]. The Italian Constitution is an example where the issues of environment, agriculture, food and landscape have always been divided into legal terms and, therefore, into sectors [67].

Regarding environmental problems, it has been documented that ecologists through experience in agricultural systems can understand, recognize and sometimes predict, at least qualitatively, the effects of pesticide applications, fertilizer use patterns, altered drainage, new crop elections and crop rotation, modifications of agricultural habitats, populations of edaphic macrofauna, demographic changes and the consequences of altering prey-predator interactions [68]. These experiences can be found in French agriculture, where emissions of greenhouse gases, water and soil pollution, the use of natural resources, land use and animal and plant biodiversity are addressed [69]. Another problem of great importance is contextualized in the European agrarian history, which lies over the hypothesis of the privilege of the privatization of land and the uses of water [70].

\subsubsection{Food Security and Sovereignty}

The search for food security and sovereignty as an essential part of agroecology was an essential element that emerged from the analysis of the documents regarding the use of the concept as a social movement for the European context, manifesting the need for a transformation of the agroecological territories in this sense. The documents reveal the society's concern for a production and consumption of safe and sufficient food that improves market demands. In this regard, Tommasi [71] highlighted the following: "We can demonstrate the need to regulate agricultural activity in a way that goes beyond the demands of market logic. We must also recognize the importance of standards in agri-food law that enables consumers to make informed choices. In contemporary society, consumers often choose products not only for their quality or price but on the basis of other intangible values".

Other studies report that rights for healthy eating, responsible consumption, access to land, preservation of agricultural ecosystems and depopulation of rural areas have been some of the issues discussed in the core of the agroecological movement [72]. In addition, small-scale agricultural production is part of the market-oriented reforms, the appropriation of agrarian, peasant and transnational movements [73]. From there emerges the discussion over the problem of access to food and high fuel costs, which represents the latest in limits and crises that have been transcended by capital, as the relationship of capital, capitalism and the agricultural revolution, which manifests itself as an increase of agricultural production costs, energy production and other primary sectors [74]. In a particular case in Norway, it was reported how producers and consumers participated in Community Supported Agriculture (CSA). Which is seen as an act of transformation towards changes in the food system, generating in these social actors different values and motivating them to the desire for a production and food system compatible with the environment, justice, health, participation and communication [75]. These actions highlight the demand for food sovereignty and the use of agroecology as an horizon for a transformation in the organization of rural territories [72].

\subsection{Scales of Agroecology Analysis}

\subsubsection{Farming System}

In this scale, investigations are directed to the following aspects: pests, diseases, management and yield of crops, biodiversity, soil practices, seeds, genetically modified organisms, energy, nutrients, crop modeling, use of mycorrhizae, biofertilizers and ecological factors (altitude, soil condition, temperature, precipitation, soil $\mathrm{pH}$ and texture, etc.). The farming system scale is related to physical and biological factors, both as part of the first level of analysis of agroecology. This way, the concept 
of agroecology presents mostly basic research works. In contrast, the text quotes how some authors address these issues:

"But, spatial variability analyses of the influence of plant cover technics, surface waste management, direct sowing and diversity of crop rotation in France show that these technics are practiced independently of each other, with distinct spatial logic" Laurent [76].

"In this study, we evaluated how the ranking of systems changes when different metrics of agricultural production (economic gross margin vs. energy output) and resource use (nutrients inputs and surpluses, fossil energy inputs, economic costs) are used" Castoldi and Bechini [77].

In this scale of agroecological research, the diversity of living organisms has long been the pillar of agricultural activity and its innovations. However, since the end of the 19th century, particularly in the industrialized countries, the increases in yields have been based on new technologies that deny the biological reality of agriculture and end up artificializing agricultural environments [37]. This situation has changed the links between agriculture and environment, which was reflected in the dynamics of agricultural research that have been questioned by environmental problems, although certain frontier research remains strong [78]. The findings show the main attention over crops, such as cotton (Gossypium sp.), Cacao (Theobroma cacao), grasses, vines, legumes, cauliflower (Brassica oleracea), amaranth (Amaranthus), rice (Oryza sativa), sunflower (Helianthus annuus), beans (Phaseolus vulgaris), corn (Zea mays), wheat (Triticum spp.), oilseeds, tomatoes (Solanum lycopersicum), coffee (Coffea sp.), sugar beet (Beta vulgaris), potato (Solanum tuberosum) and rapeseed (Brassica napus), just to mention some that are important as food (human and animal). Given this relevance, some authors emphasized that more research is needed for a better understanding of the environmental parameters that affect the efficiency of these products, particularly in agricultural crops [79]. Since they considered that, with an agroecological approach, the present problems could be solved, as ecosystems reflect an image of stability and resilience frequently attributed to their complexity and the rich pattern resulting from connections between species [80].

Besides this, a connection was identified between the authors of the analyzed studies, who perceive and visualize a more organic and ecological agriculture, directing their proposals towards the futuristic achievement of agricultural sustainability. For example, Alaphilippe, Simon, Brun, Hayer and Gaillard [48] perceived that conventional agricultural systems depend on high inputs of toxic fertilizers and pesticides that pose a threat to human and environmental health. They argued: "Such issues are rapidly changing agriculture in Europe. As a consequence sustainable production systems are currently developed as safer alternatives, for instance organic and low-input systems use of mechanical and biological methods versus toxic substances".

Considering these findings, some results suggest that organic agriculture performs better than conventional agriculture for almost all types of crops when the use of energy is expressed in a unit area [80]. Some works have been concerned with the identification of underlying ecological processes and management strategies related to the parallel provision of ecosystem services, food production and regulatory services [81]. Hence, it is observed that the disciplines in the field of research, at the scale of the cultivation system, act as facilitators of scientific information and generators of knowledge of a variety of crops, which can validate their results in a framework of public policies.

\subsubsection{Agroecosystems}

The scale of analysis of agroecosystems within agroecology has been used to a lesser degree and, usually, it has been observed that agroecosystems consider only physical and biological aspects. However, we have analyzed that nowadays the scale of agroecosystems as a unit of analysis is studied from the Systems Approach, considering not only of the basic aspects of ecology, but also social and political aspects in the context of decision makers (farmers) in the agroecosystem. This leads to reconsider what some authors share, more in the sense where agroecology was initially focused, 
on agroecosystems, and then, on the broader agri-food systems, in response to the problems arising from an increasingly globalized and industrialized agri-food system [28]. Therefore, rethinking the scope of agroecology and evolving the scientific meaning of the concept [82].

"The agroecosystem concept is regarded as an epistemological tool for creating an ontology or representation of agriculture based on a systems view" Caporali [83].

It is highlighted that, at this scale, the term "agroecosystem" is perceived by some authors as a construct of analysis to mark patterns of action in agroecology; on the other hand, it is focused on the conservation of natural resources and linked to a political agroecology that address sustainable agroecosystems. According to the reviews, they are those that tend to have a positive impact on natural, social and human capital [84]. They can be addressed in a fruitful way within an analytical framework that considers agricultural development as a balance between co-evolution processes that involve agriculture and the surrounding ecological and socio-economic systems [85] to achieve an understanding of the benefits of ecological and agronomic management, its manipulation and redesign [86]. Regarding to this definition, Molina [7] indicated that there is a narrow relationship between the dynamics of the agroecosystems and political factors. Therefore, in the agroecological transition of agriculture, political agroecology plays a crucial role.

\subsubsection{Regional Scale}

A regional scale is considered as an intermediate scale between agroecosystem and food system. It incorporates a landscape approach to the farm or production unit, defining a larger unit of analysis where agricultural and non-agricultural activities are integrated [8]. At the regional scale, some authors analyzed agroecology with a focus on territorial aspects, towards the use and price of land in rural areas, strongly linking these aspects to the need for the creation of agricultural public policies. Here, we identified four elements as quadrants that make up this scale: (1) natural resources (landscapes, soil conservation, pollination, and native varieties); (2) socio-economic impacts; (3) sovereignty and (4) human activities. All of these cause a positive or negative impact in the struggle for a sustainable agriculture. In this sense, Trabelsi et al. [87] suggested that "The process of transition to agroecology must be assessed rigorously and be appropriate for the specific conditions of the production systems and the territory". Other authors also contribute with research as the following examples:

"This paper contributes to the development and operationalisation of a methodology for land use planning and policy analysis that integrates agro-ecological and agro-economic information in such a way that it can assist policy makers in formulating and evaluating policy options at sub-regional level" Mohamed et al. [88].

"This paper has two objectives. The first one questions todays' roll of local agriculture over sustainable development of rural spaces, and the second, to what extent they build a movement to return agriculture to the territory, in a way that this fosters new relationships between both, expressed in different ways of producing, new objectives and new ties with the territory" Ramírez-García et al. [89].

In this research scheme, it is important to know which interested or involved parties have influence over the local or regional land use decisions [90]. The achievement of a sustainable agriculture is a function of the decisions that each interested party considers and the available benefits for each one. Here, the analysis of agroecology, at a regional scale, requires an interdisciplinary approach for the relevant aspects of agricultural production linked to interactions between natural processes, human activities and the environment; subsequently, with this interdisciplinarity, a condensed and complete knowledge can be achieved at field, landscape and global level [91].

Regardless of the level of organization that is considered within the approaches of agricultural systems, agroecology invites us to address co-evolutions or metabolisms in socio-ecological 
systems [78]. Agriculture can be oriented towards sustainability following a development path that improves co-evolutionary processes at the municipal level, influences many related systems and processes in the short and long term, uses knowledge of traditional agriculture and prevailing conditions, and complies with the principles of sustainable agriculture, useful to take actions and facilitate their interactions [85].

\subsubsection{Agri-Food Scale System}

We found that this scale is focused on the search for food security and sovereignty, and that, to achieve this, its relationship with sustainability is of the utmost importance, highlighting political relevance and divergence with the different actors that regulate it, where the agricultural sector is usually the most affected.

Global soil quality and food security continue declining, indicating that agriculture and the food system must be adapted [92]. To address the global challenges of food supply, biological and cultural diversity, climate change and social justice, there has been a continuous discussion between stakeholders about the future development of agricultural and food systems [93]. In this sense, some authors argued that agricultural ecosystems face the challenge of producing more products with fewer inputs simultaneously to satisfy the demand for more food and reduce the global environmental impact of agriculture [94].

"We claimed for a sustainable food system, that they are necessary not only for the health of European agroecosystems and the well-being of the farmers but also for the food autonomy of countries whose production is overturned too much to meet the European demands of animal feeding and to maintain an unsustainable diet" de Molina Navarro [95].

The agri-food sector requires a comprehensive and intersectoral policy that can meet environmental protection needs, depending on the socio-cultural context at a given time [71]. In this aspect, tendencies over food sovereignty are detected to assume a crisis of the nutritional regimen, where a romantic optimism arises on agroecological knowledge promoted by farmers, although it is lacking of modern science [96]. Migliorini and Wezel [93] emphasized that approaches to organic agriculture and agroecology offer promising contributions for the future development of sustainable agricultural production and food systems, because they are based on holistic approaches, that encourage the transformative approach of food systems, include social problems and prevent the risk of conventionalization. In the same context, in a global analysis of the epistemological currents of the concept of sustainability, the technical-biological perspective was considered through its agroecological approach, as the one with the greatest contribution to the design of sustainable agroecosystems. This is even more relevant if its application transcends from a scale of farming system to a scale of agri-food system that incorporates socio-cultural aspects (e.g., traditional knowledge) [55].

\subsection{Factors of Analysis of Agroecology}

\subsubsection{Physical-Biological Factors}

The physical-biological factor focuses on research linked to the conservation of natural resources; these studies considered biodiversity and landscaping, as well as emphasized the implementation of agricultural practices and livestock oriented to the use of organic fertilizers and an adequate capacity of the systems to provide high productivity. In this context, Dufumier [97] pointed out that "Some agricultural systems based on agro-ecology are already available in order to increase significantly the yields per hectare without excessive use of fossil fuels and pesticides". In addition, Martin and Willaume [98] reported over one comparative case study of 10 dairy farms in France with respect to their ways of adapting to climate change (specialization and intensification, eco-efficient intensification and agroecological transition): "Our results show that an agroecological transition reduces GHG emissions the most while farmers' incomes were not negatively affected indicating that the cost of associated mitigation options is affordable 
for farmers. The two dairy farms following this transition had the lowest product-related and area-related GHG emissions".

In this context, the ecological functions can be intensified to obtain a higher biomass production from the agroecosystems and the environment, in a way that has to be compatible with the principles of ecological viability [99]. In front of these results, the scientific findings, for example of landscape ecology, suggested that complex landscapes favor the biological control of insect pests by conserving the habitats of their natural enemies [62]. Faced with the fact of confronting modern societies, some authors mentioned that farmers should not only be efficient in food production, but also ensure that ecological services (pollination, pest control or conservation of biodiversity) are effective, which raises the need to reconsider the role of the environment by redesigning or evaluating the agricultural systems [78].

Based on the above, ecology is considered an essential discipline of agroecology. A clear example is shown in situations of high uncertainty (in changing climates), where environmental stresses on ecosystems are interactive, and the management or restoration of the ecosystem must adapt itself to new technologies. In this sense, some authors mentioned that this is research work of environmentalists [68], identifying ecology as a base discipline for the agroecological analysis linked to the conservation of flora and fauna, considered as the potential of ecosystem services. At the same time, they are aware of the influence of this discipline in the socio-economic and political sectors. On this matter, some elements of the authors are quoted:

"Four series of indicators were considered in this paper: indicators of habitat quality for grassland bird species, indicators of risk of disease in oilseed rape crops, indicators of risk of pollution by nitrogen fertilizer, and indicators of weed infestation" Makowski et al. [100].

"There are increasing calls to base farming and agricultural research policy on ecological principles. One such principle, the relation between crop species diversity and stability, is reviewed" Wood [101].

This demonstrates that research considering physical-biological factors in agroecology is directed at a better integration of agriculture and biodiversity for the design of systems capable of combining production with a healthy ecosystems state. It is for this reason that the choice of an agricultural system and its relationship with the biodiversity is linked to the values of a society, not precisely ecological, and the challenge for a researcher is to combine scientific quality with a reflective conscience [102]. Agroecology is then considered an innovative project linked to the field of the natural, economic and social sciences, as well as to aspects of political actions $[7,28]$, which encourage us to explore over the interface of these disciplines [38].

As part of this disciplinary interaction, something interesting has been found that is worth mentioning: research and policies aimed at the conservation of biodiversity in agricultural ecosystems are regularly less successful than expected [103]. It is thus emphasized accordingly that the general part of the law on ecosystems must determine the common legal principles that are valid to protect all ecosystems. Besides that, this law must be divided into homogeneous areas, corresponding to the different types of ecosystems according to the classifications of ecology [32].

In other words, although physical-biological factors are part of the first level of analysis in agroecology, they nevertheless consider political aspects, such as environmental laws and environmental movements. These aspects are related to the integration of agriculture and biodiversity through conservation.

\subsubsection{Social, Economic and Cultural Factors}

In this classification, we recapture the idea from which the agroecology has passed from seeing only the ecological and cultivation aspects of the system, up to the point in which the political and social aspects are involved in the forefront, which leads us to consider the following factors of analysis: social, economic and cultural.

Most of the previous things are linked to agroecological practices. In this sense, Garini et al. [104] indicated "Therefore, agroecological practices are being proposed as viable and desirable alternatives. Biophysical, 
economic, social, and political factors, matched with farmers' psychological attributes, may all be governing the choice of agricultural practices". In France, researchers and policymakers are calling for the agroecological transition of livestock and they are facing technical, economic, social and cultural obstacles [105]. In Cataluña, Spain, Guirado González et al. [106] demonstrated that the contribution of social agriculture to the provision of care services and to local development in rural and peri-urban areas is given through the construction of new economic and organizational practices and the strengthening of the agroecological paradigm. In this context, agriculture in a wider sphere is not only economic, but also social and cultural [29].

Concerning agroecological practice and thinking, civil society organizations have facilitated the link between researchers, scientists and social movements [107]. However, only family farming systems established in its local environment will be able to make the best use of the natural productive potential [97]. In this regard, Duru et al. [108] visualized a framework of a system of actors in which their behavior is determined by the norms and formal and informal agreements, interacting through the technology, with the resources of the farm, the landscape and the agri-food chain. This leads us to think that the scientific knowledge (whose aim is to promote sustainable development), which consists in the application of principles for the management of complex systems, also requires an accurate knowledge of the situation and the participation of the actors in the situation, to understand and value the local context, as well as the practices of the actors [109], to promote individual and collective learning as a source of innovation and adaptation to local situations [38].

\subsubsection{Political Factors}

The political factors considered in the analysis of agroecology are strongly linked to the agroecological movement and to agricultural and rural development. For the first, Europe is extending the agroecological movements through many local experiences that are linked to political processes. Gonzalez de Molina [7] suggested that there must exists a theoretical base showing why agroecology must involucrate political issues. In this sense, Garini, Vanwindekens, Scholberg, Wezel and Groot [104] argued that "Public policies can play a significant role as they can stimulate the adoption of innovative farming practices". In the case of the United Kingdom, the evaluation of genetically modified crops was reported, not only from the ecological point of view, but also including political reforms [68].

Another example that serves as an argument to the previous one is that the origins of the Agroecology in Europe were in Andalusia (Spain), and it was through social and political processes that there was a very important contribution to the thinking of agroecology, becoming one of the main pillars of its own definition as a scientific approach [28]. In the reflection of other authors, it is in this political context in which agroecology can play different roles, contributing to adjust the dominant regime or to transform it, using specific empowerment strategies [36].

On the other hand, and considering that the agricultural and rural development depends in large part on the implementation of the policies, agroecology in the rural development is being driven by the practices of farmers, whom the policies affect and, therefore, in the practices of the policies. To argue this idea, we discuss and describe different cases in European countries. For example, since Swedish farmers rely on subsidies and payments from rural development programs, many are very critical of their program, especially those with animals and semi-natural pastures, mainly because of the tension and opposition between the practical work of agricultural management and the relatively rigid interventions from the support scheme [110]. In the case of Sardinia, Italy, inadequate implementation of agricultural policies led to the clearing of the macchia mediterranea (a type of shrubland) together with the creation of new pastures, which has been an important factor in land degradation, intensifying tillage and water erosion [111]. In France, the milk policy threatens the future of the production, particularly in areas with a low density of milk and without production, therefore, the current policy of rural development could be insufficient to support the long-term sustainability of the farms [53]. In Denmark, Finland, Iceland, Norway and Sweden, factors such as mechanization and the Common Agricultural Policy of the European Union have affected the composition, diversity and abundance 
of the flora of weeds by the increased levels of fertilization and the application of herbicides over time [112]. This common agricultural policy has resulted in the recognition of the importance of maintaining agricultural land of high natural value, constituted by complex socio-ecological systems that depend on agricultural practices [113].

\subsection{Links between Analytical Categories of Agroecology}

Regarding the document distribution from where the textual codifications and the analytical categories emerged, it was found that more than 50\% were focused on agroecology as science, a third part as an agronomical practice and a lower percentage as a social movement. With regard to the scale, the higher number was on farming systems, followed by the regional scale and in smaller percentage agroecosystems and agri-food systems (with similar percentages in these last two). Based on this, there is a direct relationship between the percentage distribution of the documents and the categories of analysis with textual quotations, considering that the amount of textual quotations based on the categories of analysis allowed documents containing textual quotations from a multiple and/or no analysis category (Table 3).

Table 3. Coverage of the analytical categories according to the documents analyzed and encoded elements.

\begin{tabular}{cccc}
\hline & Analytical Category & $\begin{array}{c}\text { Percentage of } \\
\text { Documents Analyzed }\end{array}$ & $\begin{array}{c}\text { Percentage of Encoded Elements } \\
\text { (Textual Quotations) }\end{array}$ \\
\hline \multirow{3}{*}{ Conceptualization } & Science & 55.9 & 55.3 \\
& Social movement & 13.5 & 13.4 \\
& Agricultural practice & 30.5 & 31.2 \\
\hline \multirow{2}{*}{ Scale } & Farming system & 42.2 & 42.1 \\
& Agroecosystem & 14.9 & 15 \\
& Regional & 29.1 & 29.4 \\
\multirow{2}{*}{ Factors } & Agri-food system & 13.8 & 13.5 \\
& Physical and biological & 59.2 & 58.4 \\
& Social, cultural and & 26.1 & 26.5 \\
& economic & 14.7 & 15.1 \\
\hline
\end{tabular}

When analyzing the relationships of textual quotations (codified elements) among the ten categories of analysis, it turned out that only the concept of agroecology as science was linked to all categories of scales and factors. The agricultural practice was not linked to the category of agri-food systems, and for the case of movement, it did not show relationships with the physical-biological factors and the crop system scale (Figure 2). This narrow relationship of agroecology as science with all the scales and factors is explained due to the evolution of the concept, because agroecology has been supported by different disciplines until it became a transdisciplinary field. Agroecology has gone from dealing only with ecological and farming systems, to considering that political and social aspects should be involved from the beginning. It has surpassed the ecological perspective, until reaching to consider different approaches related to the scales and factors of analysis, like those that describe Wezel, Bellon, Doré, Francis, Vallod and David [6], who pointed out that agroecological research is at plot, field, agroecosystem and agricultural scale until considering the agri-food system. Meynard [38] described that agroecology is an innovator project, which simultaneously deals with natural, economic and social sciences, as well as with political action. This situation allows exploring new fields of knowledge on the interface of these disciplines over the agronomic effects of the biological regulations and the social systems. 


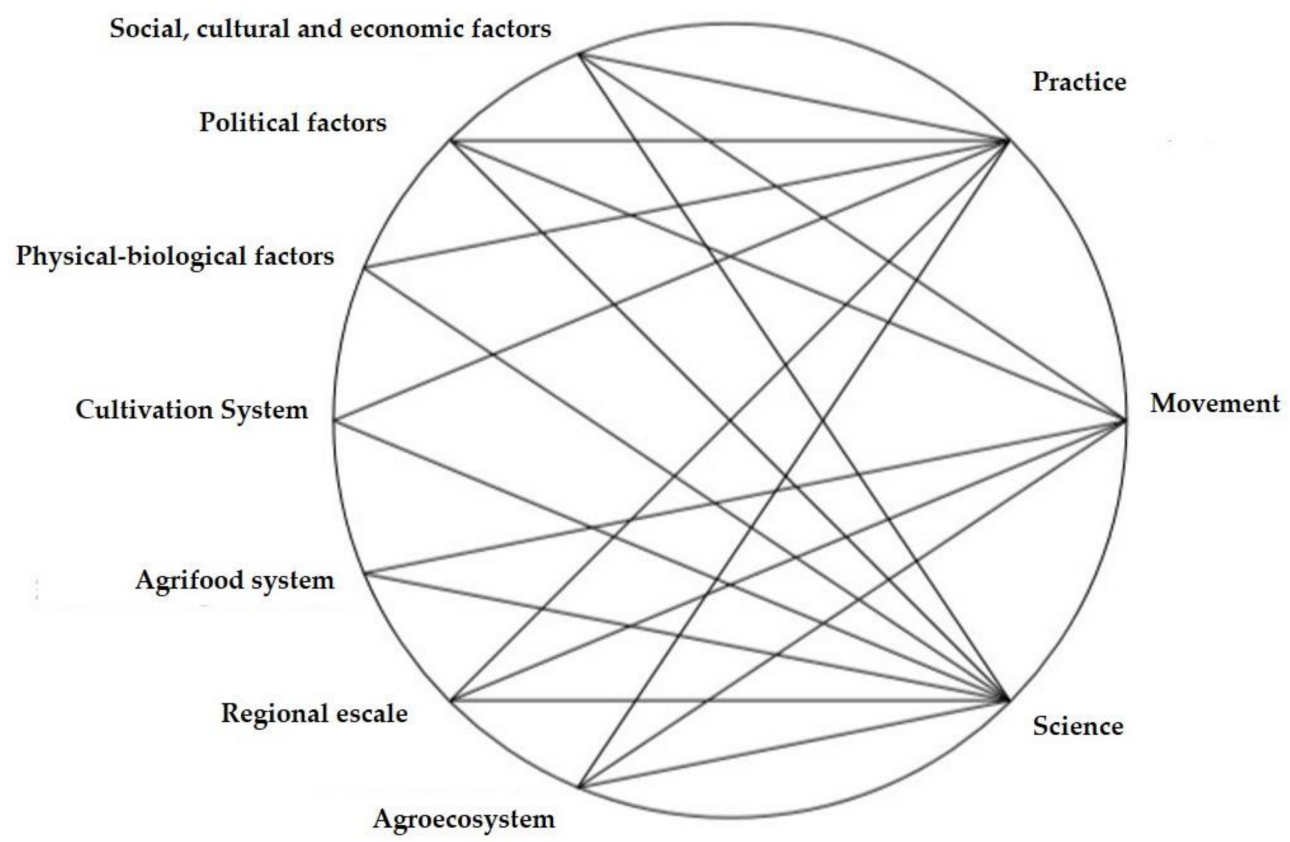

Figure 2. Relationships of the conceptualization of agroecology (science, movement and practice) with the scales and analytical factors.

The concept of agroecology as "practice" is related to three factors (physical-biological, socio-cultural-and-economic, and political), and with three scales (farming, agroecosystem and regional level). Figure 2 shows the interaction between these analytical categories marking a central trend, which is the impact of the scales and factors over the realization of different agricultural practices. For example: (1) when the relationship of the socio-cultural and economic factor determines the type of practices that will be performed; (2) the physical-biological factor determines the dimension of the practices; and (3) the political factor establishes a diversity of agronomic practices to facilitate support programs to impact on agriculture and society in general. The relationship practice-crop system is based on the function of the crop that the producer has handled; the interaction practice-regional scale is related to the nature of the benefits that can bring to a given territory. The relationship of the agroecosystem scale is interpreted as a support frame for the agroecology, where the work of the farmer and the type of production are identified. These results indicate that the degree of difficulties in the European context have increased [39]. These authors manifest a level of complexity where agroecology has a major challenge (regarding agronomical practices): to improve and to generate impacts over rural and regional agronomic development, and to address sustainable development process [46]. Of course, agricultural practices go together with generation of knowledge, and for obvious circumstances, with the problems related to agriculture, which can trigger the movements (social, scientific, etc., just to mention some).

The concept of agroecology as social movement was linked with the regional, agroecosystem and agri-food system scale. In regard to the factors, it was linked with the social, cultural, economic, and political factors (Figure 2). Considering the previous, agroecology as movement is highly influenced by the environmental movements of the regional agroecosystems and the agri-food systems. In this sense, the goal of agroecology is to achieve the security and food sovereignty, since this has been the essential part of agroecology as a movement searching for sufficient production and consumption of safe food to improve the demands. In this part, the social, cultural, economic and political factors are involved.

Highlighting that the origin and evolution of agroecology in Europe was through very marked social and political processes, making a very important contribution to the agroecological thinking [28]. Such processes or socio-political factors are very linked to agroecology as a movement. The social 
foundations of agroecology as scientific discipline and social agrarian movement have their origins in the impact of agricultural modernization, triggering a way of thinking and social movements that started since the 19th century [37]. If we consider that agroecology has also been a countermovement led by farmers against the modern agri-food system [36], the scales and factors of analysis of agroecology as a social movement contribute to the scientific debate, decision making and empowering of the farmers, contributing to the thinking and agroecological movement,

\section{Conclusions}

The development of the conceptualization of agroecology in the European countries is heterogeneous, predominating science, followed by practice and to a lesser degree as a social movement. According to the number of research documents and to the percentage of uses of the concept, we identified three groups of countries. A little group with initial contributions completely directed to science; a second group with tendency to science, followed by practice, and a little marginal to movement; and a third and more prolific group, where the practice was predominant, followed by science and to a lesser degree as movement. It is evident that the main conceptualization has contributed to the consolidation of the transdisciplinary character of agroecology; however, the absence and necessary linkage of disciplines addressing the legal aspects are noted.

In this context, a different agroecological evolution stands out for the case of Latin America and the Caribbean, where the changes of scientific and technological paradigms occur in constant reciprocity with social movements and political processes, emerging progressive governments and peasant resistance movements.

The main scale where the concept of agroecology has been applied is at the level of farming systems, followed by regional level, agroecosystems and, finally, agri-food systems. In the first one, organic agriculture is prevalent, making clear the close relationship of the concepts of sustainability and agroecology. The regional scale is focus on the use of the land, biodiversity and landscape, with an interest in translating sustainability issues to agricultural policies. With respect to the agroecosystem scale, an application of the systems approach was found, considering ecological, economic and political aspects. Finally, the agri-food system scale reinforces the global sense of agriculture from an agroecological perspective, observing the coexistence with other disciplines and emphasizes an interdisciplinary approach, where socio-political aspects are addressed, involving guarantee of food sovereignty and security. According to the scales of the use of the concept of agroecology, it has transcended from a farming system to an agri-food system, without losing its autonomy as a research with focus between both scales.

For research papers, the main factor of analysis was physical-biological, with research linked to the conservation of the natural resources, biodiversity and landscape. The emphasis is placed in efficient practices for agriculture and cattle, oriented to increase productivity and, at the same time, being compatible with ecological viability to contribute with the main challenge of farmers, food production guarantying ecological services. In these investigations, ecology is the base of agroecology. Social, economic and cultural factors have taken relevance, going from dealing only with ecological aspects until including social and cultural aspects, giving a better context to the agri-food system. The inclusion of the studies of political factors is closely linked to the agroecological movement and the call for a sustainable agricultural and rural development. In this aspect, the extension of agroecological movements in Europe is given by local experiences and policies, such as the case of transgenic organisms, which are involved in ecological issues.

In general, the conceptualization of agroecology, the levels of study (or scales) and its implicit analytical factors, show an evident evolution with qualitative and quantitative (in intention and extension) improvement. This was possible because agroecology went from the scale of farm systems to the scales of agroecosystems and agri-food systems, including more and more economic, social and cultural aspects. However, some political aspects are still missing. This consolidation in the concept has allowed the implementation of efficient agroecological practices in agriculture, cattle and landscape, 
directed towards sustainability. All these aspects make agroecology a transdisciplinary science, with society-nature as study unit. Therefore, this science cannot be framed within the current disciplinary limits; it must go to the approach of the interdisciplinary interfaces as a response to contemporary complex phenomena, which has sustained its genesis and development. We recommend a better balance among the three main conceptualizations of agroecology (science, practice and movement), establishing a dialog between the abstract and the empiric, to identify and solve study object problems (relationship nature-society). This also requires the understanding of agriculture from different perspectives to those found in this study, oriented to the use of paradigms where social actors, their development and the impacts of their social tasks in agriculture, are considered the main axis.

Acknowledgments: Authors thank the geomatics laboratory of Colegio de Postgraduados, Campus Veracruz, for support for the realization of the map.

Author Contributions: Felipe Gallardo-López contributed in research design, documents analysis, statistical analysis and article writing. Mario Alejandro Hernández-Chontal contributed in methodological design, documents analysis, using Nvivo Software and article writing. Pedro Cisneros-Saguilan contributed in research design, documents analysis, results description and article writing. Ariadna Linares-Gabriel contributed in bibliographic search, using Nivivo Software and results writing.

Conflicts of Interest: The authors declare no conflict of interest.

\section{References}

1. Altieri, M.Á. Agroecology: A new research and development paradigm for world agriculture. Agric. Ecosyst. Environ. 1989, 27, 37-46. [CrossRef]

2. Méndez, V.E.; Bacon, C.M.; Cohen, R. Agroecology as a transdisciplinary, participatory, and action-oriented approach. Agroecol. Sustain. Food Syst. 2013, 37, 3-18.

3. Wezel, A.; Jauneau, J.C. Agroecology-Interpretations, approaches and their links to nature conservation, rural development and ecotourism. In Integrating Agriculture, Conservation and Ecotourism: Examples from the Field; Campbell, W.B., Lopez Ortiz, S., Eds.; Springer: London, UK, 2011; Volume 1, pp. 1-25.

4. Méndez, V.E.; Caswell, M.; Gliessman, S.R.; Cohen, R. Integrating agroecology and participatory action research (par): Lessons from central america. Sustainability 2017, 9, 705. [CrossRef]

5. Wezel, A.; Soldat, V. A quantitative and qualitative historical analysis of the scientific discipline of agroecology. Int. J. Agric. Sustain. 2009, 7, 3-18. [CrossRef]

6. Wezel, A.; Bellon, S.; Doré, T.; Francis, C.; Vallod, D.; David, C. Agroecology as a science, a movement and a practice. A review. Agron. Sustain. Dev. 2009, 29, 503-515. [CrossRef]

7. De Molina, M.G. Agroecology and politics. How to get sustainability? About the necessity for a political agroecology. Agroecol. Sustain. Food Syst. 2013, 37, 45-59.

8. Toledo, V.M. La agroecología en latinoamérica: Tres revoluciones, una misma transformación. Agroecología 2012, 6, 37-46.

9. Wezel, A.; Brives, H.; Casagrande, M.; Clément, C.; Dufour, A.; Vandenbroucke, P. Agroecology territories: Places for sustainable agricultural and food systems and biodiversity conservation. Agroecol. Sustain. Food Syst. 2016, 40, 132-144. [CrossRef]

10. Argüello, A. Agroecology: Scientific and technological challenges for agriculture in the 21st century in latin america. Agron. Colomb. 2015, 33, 391-398. [CrossRef]

11. Gliessman, S. Transforming food systems to sustainability with agroecology. J. Sustain. Agric. 2011, 35, 823-825. [CrossRef]

12. Altieri, M.Á. Agroecología-Bases Científicas Para una Agricultura Sustentable; Nordan-Comunidad: Montevideo, Uruguay, 1999; p. 338.

13. Saj, S.; Torquebiau, E.; Hainzelin, E.; Pages, J.; Maraux, F. The way forward: An agroecological perspective for climate-smart agriculture. Agric. Ecosyst. Environ. 2017, 250, 20-24. [CrossRef]

14. Altieri, M.A.; Nicholls, C.I. Agroecology: A brief account of its origins and currents of thought in latin america. Agroecol. Sustain. Food Syst. 2017, 41, 231-237. [CrossRef] 
15. Astier, M.; Argueta, J.Q.; Orozco-Ramírez, Q.; González, M.V.; Morales, J.; Gerritsen, P.R.; Escalona, M.A.; Rosado-May, F.J.; Sánchez-Escudero, J.; Martínez Saldaña, T. Back to the roots: Understanding current agroecological movement, science, and practice in mexico. Agroecol. Sustain. Food Syst. 2017, 41, 329-348. [CrossRef]

16. Toledo, V.M.; Barrera-Bassols, N. Political agroecology in mexico: A path toward sustainability. Sustainability 2017, 9, 268. [CrossRef]

17. Kaefer, F.; Roper, J.; Sinha, P. A software-assisted qualitative content analysis of news articles: Example and reflections. Forum Qual. Soc. Res. 2015, 16. [CrossRef]

18. INC, S.S. Statistica (Data Analysis Software System) Version 7; StatSoft Inc.: Tulsa, OK, USA, 2004.

19. Tukey, J.W. Exploratory data analysis. In Addison-Wesley Series in Behavioral Science: Quantitative Methods; Addison-Wesley: Reading, MA, USA, 1977.

20. Chalate-Molina, H.; Gallardo-López, F.; Pérez-Hernández, P.; Paul Lang-Ovalle, F.; Ortega-Jiménez, E.; Vilaboa Arroniz, J. Características del sistema de producción bovinos de doble propósito en el estado de morelos, méxico. Zootec. Trop. 2010, 28, 329-339.

21. Gliessman, S.R. Agroecology: Researching the Ecological Basis for Sustainable Agriculture; Springer: Berlin, Germany, 1990; pp. 3-10.

22. Flores-Sánchez, D.; Navarro-Garza, H.; Carballo-Carballo, A.; Pérez-Olvera, M. Sistemas de cultivo y biodiversidad periurbana: Estudio de caso en la cuenca del río texcoco. Agric. Soc. Desarro. 2012, 9, $209-223$.

23. Gallardo-López, F.; Rodríguez-Chessani, M.A.; Martínez-Garza, S.E.; Chalate-Molina, H.; Cisneros-Saguilan, P. El agroecosistema como sistema complejo. In Memorias del IV Coloquio sobre Agroecosistemas y Sustentabilidad; Octavio Ruiz Rosado, O., Álvarez Ávila, M.C., Hernández Mendo, O., Pérez Flores, J., y Sol Sánchez, A., Eds.; Sociedad Mexicana de Agricultura Sostenible A. C. y Colegio de Postgraduados San Luis Potosí: San Luis Potosí, Mexico, 2011; pp. 8-16.

24. Fonte, M. Food systems, consumption models and risk perception in late modernity. Int. J. Sociol. Agric. Food 2002, 10, 13-21.

25. García, Y.; Ramírez, W.; Sánchez, S. Indicadores de la calidad de los suelos: Una nueva manera de evaluar este recurso. Pastos y Forrajes 2012, 35, 125-138.

26. Martínez, R. Fundamentos culturales, sociales y económicos de la agroecología. Revista de Ciencias Sociales (Cr) 2004, 103-104, 93-102.

27. De Molina, M.G.l.; Caporal, F.R. Agroecología y política. cómo conseguir la sustentabilidad? Sobre la necesidad de una agroecología política. Agroecología 2013, 8, 35-43.

28. González de Molina, M.; Guzmán, G.I. On the andalusian origins of agroecology in spain and its contribution to shaping agroecological thought. Agroecol. Sustain. Food Syst. 2017, 41, 256-275. [CrossRef]

29. Ruiz-Rosado, O. Agroecología: Una disciplina que tiende a la transdisciplina. Interciencia 2006, 31, 140-145.

30. Monteduro, M.; Buongiorno, P.; Di Benedetto, S.; Isoni, A. Law and Agroecology: A Transdisciplinary Dialogue; Springer: Berlin, Germany, 2015.

31. Hospes, O. Addressing law and agroecosystems, sovereignty and sustainability from a legal pluralistic perspective. In Law and Agroecology: A Transdisciplinary Dialogue; Monteduro, M., Buongiorno, P., Di Benedetto, S., Isoni, A., Eds.; Springer: Berlin/Heidelberg, Germany, 2015; pp. 47-56.

32. Monteduro, M. Environmental Law and Agroecology. Transdisciplinary Approach to Public Ecosystem Services as a New Challenge for Environmental Legal Doctrine; Kluwer Law International: Alphen aan den Rijn, The Netherlands, 2013; Volume 22, pp. 2-11.

33. Buongiorno, P. Agriculture, environment and law between ancient experiences and present knowledge: Some remarks. In Law and Agroecology: A Transdisciplinary Dialogue; Monteduro, M., Buongiorno, P., Di Benedetto, S., Isoni, A., Eds.; Springer: Berlin/Heidelberg, Germany, 2015; pp. 87-98.

34. Buia, G.; Antonucci, M. The rural development programme (rdp) as a strategic tool for linking legal and agroecological perspectives. In Law and Agroecology: A Transdisciplinary Dialogue; Monteduro, M., Buongiorno, P., Di Benedetto, S., Isoni, A., Eds.; Springer: Berlin/Heidelberg, Germany, 2015; pp. 151-182.

35. Sanderson Bellamy, A.; Ioris, A. Addressing the knowledge gaps in agroecology and identifying guiding principles for transforming conventional agri-food systems. Sustainability 2017, 9, 330. [CrossRef]

36. Levidow, L.; Pimbert, M.; Vanloqueren, G. Agroecological research: Conforming-Or transforming the dominant agro-food regime? Agroecol. Sustain. Food Syst. 2014, 38, 1127-1155. [CrossRef] 
37. Hainzelin, É.; Nouaille, C. The diversity of living organisms: The engine for ecological functioning. In Cultivating Biodiversity to Transform Agriculture; Hainzelin, É., Ed.; Springer: Dordrecht, The Netherlands, 2013; pp. 11-44.

38. Meynard, J.-M. L'agroécologie, un nouveau rapport aux savoirs et à l'innovation. OCL 2017, 24, D303. [CrossRef]

39. Bergez, J.E.; Chabrier, P.; Gary, C.; Jeuffroy, M.H.; Makowski, D.; Quesnel, G.; Ramat, E.; Raynal, H.; Rousse, N.; Wallach, D.; et al. An open platform to build, evaluate and simulate integrated models of farming and agro-ecosystems. Environ. Model. Softw. 2013, 39, 39-49. [CrossRef]

40. Struik, P.C.; Kuyper, T.W. Sustainable intensification in agriculture: The richer shade of green. A review. Agron. Sustain. Dev. 2017, 37, 39. [CrossRef]

41. Doré, T.; Makowski, D.; Malézieux, E.; Munier-Jolain, N.; Tchamitchian, M.; Tittonell, P. Facing up to the paradigm of ecological intensification in agronomy: Revisiting methods, concepts and knowledge. Eur. J. Agron. 2011, 34, 197-210. [CrossRef]

42. Bonny, S. L'agriculture écologiquement intensive: Nature et défis. Agricultures 2011, 20. [CrossRef]

43. Tornaghi, C. Urban agriculture in the food-disabling city: (re)Defining urban food justice, reimagining a politics of empowerment. Antipode 2017, 49, 781-801. [CrossRef]

44. Schröder, P.; Huber, B.; Olazábal, U.; Kämmerer, A.; Munch, J.C. Land use and sustainability: Fam research network on agroecosystems. Geoderma 2002, 105, 155-166. [CrossRef]

45. Nesme, T.; Lescourret, F.; Bellon, S.; Habib, R. Is the plot concept an obstacle in agricultural sciences? A review focussing on fruit production. Agric. Ecosyst. Environ. 2010, 138, 133-138. [CrossRef]

46. Darnhofer, I.; Fairweather, J.; Moller, H. Assessing a farm's sustainability: Insights from resilience thinking. Int. J. Agric. Sustain. 2010, 8, 186-198. [CrossRef]

47. Bullock, J.M.; Dhanjal-Adams, K.L.; Milne, A.; Oliver, T.H.; Todman, L.C.; Whitmore, A.P.; Pywell, R.F. Resilience and food security: Rethinking an ecological concept. J. Ecol. 2017, 105, 880-884. [CrossRef]

48. Alaphilippe, A.; Simon, S.; Brun, L.; Hayer, F.; Gaillard, G. Life cycle analysis reveals higher agroecological benefits of organic and low-input apple production. Agron. Sustain. Dev. 2013, 33, 581-592. [CrossRef]

49. Blazy, J.-M.; Carpentier, A.; Thomas, A. The willingness to adopt agro-ecological innovations: Application of choice modelling to caribbean banana planters. Ecol. Econ. 2011, 72, 140-150. [CrossRef]

50. Rusch, A.; Delbac, L.; Thiéry, D. Grape moth density in bordeaux vineyards depends on local habitat management despite effects of landscape heterogeneity on their biological control. J. Appl. Ecol. 2017, 54, 1794-1803. [CrossRef]

51. Phocas, F.; Belloc, C.; Bidanel, J.; Delaby, L.; Dourmad, J.Y.; Dumont, B.; Ezanno, P.; Fortun-Lamothe, L.; Foucras, G.; Frappat, B.; et al. Review: Towards the agroecological management of ruminants, pigs and poultry through the development of sustainable breeding programmes. Ii. Breeding strategies. Anim. Int. J. Anim. Biosci. 2016, 10, 1760-1769. [CrossRef] [PubMed]

52. Aubron, C.; Noël, L.; Lasseur, J. Labor as a driver of changes in herd feeding patterns: Evidence from a diachronic approach in mediterranean France and lessons for agroecology. Ecol. Econ. 2016, 127, 68-79. [CrossRef]

53. Dervillé, M.; Allaire, G.; Maigné, É.; Cahuzac, É. Internal and contextual drivers of dairy restructuring: Evidence from french mountainous areas and post-quota prospects. Agric. Econ. 2017, 48, 91-103. [CrossRef]

54. Girard, N.; Duru, M.; Hazard, L.; Magda, D. Categorising farming practices to design sustainable land-use management in mountain areas. Agron. Sustain. Dev. 2008, 28, 333-343. [CrossRef]

55. Cisneros-Saguilán, P.; Gallardo-López, F.; López-Ortiz, S.; Ruiz, R.O.; Herrera-Haro, J.G.; Hernández-Castro, E. Current epistemological perceptions of sustainability and its application in the study and practice of cattle production: A review. Agroecol. Sustain. Food Syst. 2015, 39, 885-906. [CrossRef]

56. Herrero, M.; Havlík, P.; Valin, H.; Notenbaert, A.; Rufino, M.C.; Thornton, P.K.; Blümmel, M.; Weiss, F.; Grace, D.; Obersteiner, M. Biomass use, production, feed efficiencies, and greenhouse gas emissions from global livestock systems. Proc. Natl. Acad. Sci. USA 2013, 110, 20888-20893. [CrossRef] [PubMed]

57. Sommer, S.G.; Olesen, J.E.; Petersen, S.O.; Weisbjerg, M.R.; Valli, L.; Rodhe, L.; BÉLine, F. Region-specific assessment of greenhouse gas mitigation with different manure management strategies in four agroecological zones. Glob. Chang. Biol. 2009, 15, 2825-2837. [CrossRef]

58. Vaarst, M.; Alrøe, H.F. Concepts of animal health and welfare in organic livestock systems. J. Agric. Environ. Ethics 2012, 25, 333-347. [CrossRef] 
59. Coudrain, V.; Hedde, M.; Chauvat, M.; Maron, P.-A.; Bourgeois, E.; Mary, B.; Léonard, J.; Ekelund, F.; Villenave, C.; Recous, S. Temporal differentiation of soil communities in response to arable crop management strategies. Agric. Ecosyst. Environ. 2016, 225, 12-21. [CrossRef]

60. Peeters, A.; Dendoncker, N.; Jacobs, S. Chapter 22-Enhancing ecosystem services in Belgian agriculture through agroecology: A vision for a farming with a future. In Ecosystem Services; Elsevier: Boston, MA, USA, 2013; pp. 285-304.

61. De la Rosa, D.; Anaya-Romero, M.; Diaz-Pereira, E.; Heredia, N.; Shahbazi, F. Soil-specific agro-ecological strategies for sustainable land use-A case study by using microleis dss in sevilla province (spain). Land Use Policy 2009, 26, 1055-1065. [CrossRef]

62. Salliou, N.; Barnaud, C. Landscape and biodiversity as new resources for agro-ecology? Insights from farmers' perspectives. Ecol. Soc. 2017, 22. [CrossRef]

63. Smith, J.; Pearce, B.D.; Wolfe, M.S. A european perspective for developing modern multifunctional agroforestry systems for sustainable intensification. Renew. Agric. Food Syst. 2012, 27, 323-332. [CrossRef]

64. Tillie, P.; Dillen, K.; Rodríguez-Cerezo, E. Perception of coexistence measures by farmers in five european union member states les mesures de coexistence: Perception par les agriculteurs de cinq états membres de l'union européenne wahrnehmung von koexistenzmaßnahmen in der landwirtschaft in fünf mitgliedsstaaten der europäischen union. EuroChoices 2016, 15, 17-23.

65. Wickson, F.; Binimelis, R.; Herrero, A. Should organic agriculture maintain its opposition to gm? New techniques writing the same old story. Sustainability 2016, 8, 1105. [CrossRef]

66. Hermon, C. The relationship between agricultural law and environmental law in france. In Law and Agroecology: A Transdisciplinary Dialogue; Monteduro, M., Buongiorno, P., Di Benedetto, S., Isoni, A., Eds.; Springer: Berlin/Heidelberg, Germany, 2015; pp. 241-263.

67. Troisi, M. Environment, landscape, agriculture, and food in the framework of state and regional legislative powers as per art. 117 of the italian constitution. In Law and Agroecology: A Transdisciplinary Dialogue; Monteduro, M., Buongiorno, P., Di Benedetto, S., Isoni, A., Eds.; Springer: Berlin/Heidelberg, Germany, 2015; pp. 207-226.

68. Ormerod, S.J.; Marshall, E.J.P.; Kerby, G.; Rushton, S.P. Meeting the ecological challenges of agricultural change: Editors' introduction. J. Appl. Ecol. 2003, 40, 939-946. [CrossRef]

69. Doreau, M.; Farruggia, A.; Veysset, P. Environmental amenities and impact of French farms for beef production. INRA Prod. Anim. 2017, 30, 165-177.

70. Lázaro, J.F. Los usos de la historia: Una reflexión sobre el agua. Vínculos de Historia 2012, 1, 115-125.

71. Tommasi, S. The agri-food market and eco-oriented consumer law: Towards a new model. In Law and Agroecology: A Transdisciplinary Dialogue; Monteduro, M., Buongiorno, P., Di Benedetto, S., Isoni, A., Eds.; Springer: Berlin/Heidelberg, Germany, 2015; pp. 321-332.

72. Montesinos, X.A.; Pérez, S.O. La ruralidad del 15-m. Iniciativas desde el movimiento agroecológico alicantino. ACME Int. J. Crit. Geogr. 2015, 14, 185-199.

73. Narotzky, S. Where have all the peasants gone? Annu. Rev. Anthropol. 2016, 45, 301-318. [CrossRef]

74. Moore, J.W. The end of the road? Agricultural revolutions in the capitalist world-ecology, 1450-2010. J. Agrar. Chang. 2010, 10, 389-413. [CrossRef]

75. Hvitsand, C. Community supported agriculture (csa) as a transformational act—Distinct values and multiple motivations among farmers and consumers. Agroecol. Sustain. Food Syst. 2016, 40, 333-351. [CrossRef]

76. Laurent, F. L'agriculture de conservation et sa diffusion en france et dans le monde. Cybergeo Rev. Eur. J. Geogr. 2015. [CrossRef]

77. Castoldi, N.; Bechini, L. Energy, nutrient and economic cross indicators of cropping systems in northern Italy. Ital. J. Agron. 2010, 5, 19-26. [CrossRef]

78. Bellon, S.; Hemptinne, J.-L. Reshaping boundaries between farming systems and the environment. In Farming Systems Research into the 21st Century: The New Dynamic; Darnhofer, I., Gibbon, D., Dedieu, B., Eds.; Springer: Dordrecht, The Netherlands, 2012; pp. 307-333.

79. Le Mire, G.; Nguyen, M.L.; Fassotte, B.; du Jardin, P.; Verheggen, F.; Delaplace, P.; Jijakli, M.H. Implementing plant biostimulants and biocontrol strategies in the agroecological management of cultivated ecosystems. A review/intégrer les biostimulants et les stratégies de biocontrôle dans la gestion agroécologique des écosystèmes cultivés (synthèse bibliographique). Biotechnol. Agron. Soc. Environ. 2016, 20, 299. 
80. Smith, L.; Williams, A.; Pearce, B. The Energy Efficiency of Organic Agriculture: A Review; Cambridge University Press: Cambridge, UK, 2014; Volume 30, pp. 1-22.

81. Gaba, S.; Lescourret, F.; Boudsocq, S.; Enjalbert, J.; Hinsinger, P.; Journet, E.-P.; Navas, M.-L.; Wery, J.; Louarn, G.; Malézieux, E.; et al. Multiple cropping systems as drivers for providing multiple ecosystem services: From concepts to design. Agron. Sustain. Dev. 2015, 35, 607-623. [CrossRef]

82. Sevilla Guzmán, E.; Woodgate, G. Agroecology: Foundations in agrarian social thought and sociological theory. Agroecol. Sustain. Food Syst. 2013, 37, 32-44.

83. Caporali, F. History and development of agroecology and theory of agroecosystems. In Law and Agroecology: A Transdisciplinary Dialogue; Monteduro, M., Buongiorno, P., Di Benedetto, S., Isoni, A., Eds.; Springer: Berlin/Heidelberg, Germany, 2015; pp. 3-29.

84. Pretty, J.; Bharucha, Z.P. Sustainable intensification in agricultural systems. Ann. Bot. 2014, 114, 1571-1596. [CrossRef] [PubMed]

85. Saifi, B.; Drake, L. A coevolutionary model for promoting agricultural sustainability. Ecol. Econ. 2008, 65, 24-34. [CrossRef]

86. Pretty, J. Agricultural sustainability: Concepts, principles and evidence. Philos. Trans. R. Soc. B Biol. Sci. 2008, 363, 447-465. [CrossRef] [PubMed]

87. Trabelsi, M.; Mandart, E.; Le Grusse, P.; Bord, J.-P. How to measure the agroecological performance of farming in order to assist with the transition process. Environ. Sci. Pollut. Res. 2016, 23, 139-156. [CrossRef] [PubMed]

88. Mohamed, A.A.; Sharifi, M.A.; van Keulen, H. An integrated agro-economic and agro-ecological methodology for land use planning and policy analysis. Int. J. Appl. Earth Obs. Geoinf. 2000, 2, 87-103. [CrossRef]

89. Ramírez-García, S.; Mancha-Cáceres, O.I.; Del-Canto-Fresno, C. Las agriculturas territorializadas, oportunidades y retos frente al paradigma agroindustrial. Documents D'anàlisi Geogràfica 2016, 62, 639-660. [CrossRef]

90. Hauck, J.; Schmidt, J.; Werner, A. Using social network analysis to identify key stakeholders in agricultural biodiversity governance and related land-use decisions at regional and local level. Ecol. Soc. 2016, 21. [CrossRef]

91. Martin, K.; Sauerborn, J. Introduction. In Agroecology; Springer: Dordrecht, The Netherlands, 2013; pp. 1-7.

92. Ball, B.C.; Hargreaves, P.R.; Watson, C.A. A framework of connections between soil and people can help improve sustainability of the food system and soil functions. Ambio 2017, 47, 269-283. [CrossRef] [PubMed]

93. Migliorini, P.; Wezel, A. Converging and diverging principles and practices of organic agriculture regulations and agroecology. A review. Agron. Sustain. Dev. 2017, 37, 63. [CrossRef]

94. Martinez, J.; Pellerin, S. Optimizing $\mathrm{n}$ and $\mathrm{p}$ recycling from organic amendments via agroecological incentives and concepts-Scope for further developments. Soil Use Manag. 2016, 32, 64-72. [CrossRef]

95. De Molina Navarro, M.G. Agroecology and politics: On the importance of public policies in europe. In Law and Agroecology: A Transdisciplinary Dialogue; Monteduro, M., Buongiorno, P., Di Benedetto, S., Isoni, A., Eds.; Springer: Berlin/Heidelberg, Germany, 2015; pp. 395-410.

96. Jansen, K. The debate on food sovereignty theory: Agrarian capitalism, dispossession and agroecology. J. Peasant Stud. 2015, 42, 213-232. [CrossRef]

97. Dufumier, M. Enjeux alimentaires mondiaux et agricultures familiales. Bulletin de l'association de Géographes Français. Géographies 2015, 92, 413-421. [CrossRef]

98. Martin, G.; Willaume, M. A diachronic study of greenhouse gas emissions of french dairy farms according to adaptation pathways. Agric. Ecosyst. Environ. 2016, 221, 50-59. [CrossRef]

99. Griffon, M. Éléments théoriques en agroécologie: L'intensivité écologique. OCL 2017, 24, D302. [CrossRef]

100. Makowski, D.; Tichit, M.; Guichard, L.; Van Keulen, H.; Beaudoin, N. Measuring the accuracy of agro-environmental indicators. J. Environ. Manag. 2009, 90, S139-S146. [CrossRef] [PubMed]

101. Wood, D. Ecological principles in agricultural policy: But which principles? Food Policy 1998, $23,371-381$. [CrossRef]

102. Barret, P.; Bourguet, D.; Duée, P.-H.; Gerber, S.; Le Roux, X.; Tixier-Boichard, M. Éthique et biodiversité: Questions posées à et par la recherche agronomique. Nat. Sci. Soc. 2016, 24, 270-276. [CrossRef]

103. Moonen, A.-C.; Bàrberi, P. Functional biodiversity: An agroecosystem approach. Agric. Ecosyst. Environ. 2008, 127, 7-21. [CrossRef] 
104. Garini, C.S.; Vanwindekens, F.; Scholberg, J.M.S.; Wezel, A.; Groot, J.C.J. Drivers of adoption of agroecological practices for winegrowers and influence from policies in the province of trento, italy. Land Use Policy 2017, 68, 200-211. [CrossRef]

105. Beudou, J.; Martin, G.; Ryschawy, J. Cultural and territorial vitality services play a key role in livestock agroecological transition in france. Agron. Sustain. Dev. 2017, 37, 36. [CrossRef]

106. Guirado González, C.; Badía Perpinyà, A.; Tulla i Pujol, A.F.; Vera Martín, A.; Valldeperas Belmonte, N. La agricultura social en catalunya: Innovación social y dinamización agroecológica para la ocupación de personas en riesgo de exclusión. AGER Rev. Estud. Sobre Despoblación y Desarro. Rural 2014, 17, 65-97.

107. Levidow, L. European transitions towards a corporate-environmental food regime: Agroecological incorporation or contestation? J. Rural Stud. 2015, 40, 76-89. [CrossRef]

108. Duru, M.; Fares, M.H.; Therond, O. Un cadre conceptuel pour penser maintenant (et organiser demain) la transition agroécologique de l'agriculture dans les territoires. Cah. Agric. 2014, 23, 84-95.

109. Hazard, L.; Steyaert, P.; Martin, G.; Couix, N.; Navas, M.-L.; Duru, M.; Lauvie, A.; Labatut, J. Mutual learning between researchers and farmers during implementation of scientific principles for sustainable development: The case of biodiversity-based agriculture. Sustain. Sci. 2017, 13, 517-530. [CrossRef]

110. Eksvärd, K.; Marquardt, K. From change to transition? Learning from environmental protection activities in sweden. Agroecol. Sustain. Food Syst. 2018, 42, 189-209. [CrossRef]

111. Zucca, C.; Canu, A.; Previtali, F. Soil degradation by land use change in an agropastoral area in sardinia (italy). CATENA 2010, 83, 46-54. [CrossRef]

112. Andreasen, C.; Streibig, J.C. Evaluation of changes in weed flora in arable fields of nordic countries-Based on danish long-term surveys. Weed Res. 2011, 51, 214-226. [CrossRef]

113. Lomba, A.; Strohbach, M.; Jerrentrup, J.S.; Dauber, J.; Klimek, S.; McCracken, D.I. Making the best of both worlds: Can high-resolution agricultural administrative data support the assessment of high nature value farmlands across europe? Ecol. Indic. 2017, 72, 118-130. [CrossRef]

(C) 2018 by the authors. Licensee MDPI, Basel, Switzerland. This article is an open access article distributed under the terms and conditions of the Creative Commons Attribution (CC BY) license (http:/ / creativecommons.org/licenses/by/4.0/). 